УДК 339.944 .2

\title{
МІЖДИСЦИПЛІНАРНИЙ ПІДХІД ДО ФОРМУВАННЯ УНІВЕРСАЛЬНИХ КОМПЕТЕНЦІЙ У ПРОЦЕСІ ВИВЧЕННЯ ДИСЦИПЛІН ОСВВТНЬОЇ ПРОГРАМИ «МІЖНАРОДНИЙ БІЗНЕС»
}

\section{INTERDISCIPLINARY APPROACH TO THE FORMATION OF UNIVERSAL COMPETENCIES IN THE PROCESS OF STUDYING THE DISCIPLINES OF THE EDUCATIONAL PROGRAM "INTERNATIONAL BUSINESS"}

\author{
Ступницький Олексій Іванович \\ кандидат економічних наук, профресор, \\ Київський національний університет імені Тараса Шевченка \\ ORCID: https://orcid.org/0000-0002-5508-5625 \\ Приятельчук Олена Анатоліївна \\ доктор економічних наук, доцент, \\ Київський національний університет імені Тараса Шевченка \\ ORCID: https://orcid.org/0000-0002-5222-452X \\ Stupnytskyy Oleksiy, Pryiatelchuk Olena \\ Taras Shevchenko National University of Kyiv
}

\begin{abstract}
У статті розглядаються проблеми впровадження та використання міждисциплінарного підходу у профеесійній підготовці майбутніх фрахівців за спеціальністю «міжнародний бізнес». Досліджуються міждисциплінарні зв'язки, які забезпечують міждисциплінарний підхід у ссрері освіти, наукова база, а також система навчання як комплекс фрундаментальних і таксономічних дисциплін. Здійснений опис та надана характеристика специфіки майбутньої професійної діяльності спеціалістів у ссрері міжнародного бізнесу, світової економіки і міжнародних економічних відносин. Використання міждисциплінарного підходу у професійній підготовці майбутніх спеціалістів розглядається як частина процесу фрормування їх професійної компетентності шляхом реалізації зв'язків із дисциплінами гуманітарної, соціально-економічної та природно-наукової підготовки. Зі спрямованістю на ефективне навчання розглянуті міждисциплінарні зв'язки, погодженість учбових програм, детерміновані дидактичними цілями та змістом. При компетентносному підході міждисциплінарні зв'язки дозволяють переносити знання, вміння та навички із одної сорери науки і професійної діяльності до інших. Міждисциплінарний підхід спрямований на зв'язок дисциплін, коли згладжуються протиріччя в опануванні ідей, методів і прийомів дослідження між науками та відбувається комплексне використання у професійній діяльності теорії і практики, отриманих на основі вивчених дисциплін. Розглянуті як суттєві переваги, так і проблеми, що виникають при використанні міждисциплінарного підходу. Доведено, що вміння та навички майбутніх бакалаврів і магістрів спеціальності «міжнародний бізнес» фрормуються під впливом вивчення і взаємозв'язку з іншими дисциплінами. Обґрунтована необхідність посилення ролі природничої і методологічної складових у викладанні дисциплін спеціальності «міжнародний бізнес», а також активізації використання різних методів для поліпшення сприйняття і засвоєння різних аспектів фрункціонування та розвитку світової економіки як цілісної системи.

Ключові слова: міждисциплінарний підхід, міждисциплінарні зв'язки, компетенція, інтегративний підхід, понятійно-термінологічний апарат, професійна підготовка за спеціальністю «міжнародний бізнес».
\end{abstract}

В статье рассматриваются проблемы внедрения и использования междисциплинарного подхода в профрессиональной подготовке будущих бакалавров и магистров по специальности «международный бизнес». Исследуются междисциплинарные связи, обеспечивающие междисциплинарный подход к образованию, научная база, а также система обучения как комплекс фундаментальных и таксономических дисциплин. Осуществлено описание и дана характеристика специфики будущей профессиональной деятельности специалистов в сорере международного бизнеса, мировой экономики и международных экономических отношений. Использование междисциплинарного подхода в профессиональной подготовке будущих специалистов 
рассматривается как часть процесса фрормирования их профессиональной компетентности путем реализации связей с дисциплинами гуманитарной, социально-экономической и естественнонаучной подготовки. С направленностью на эфффективность обучения рассмотрены междисциплинарные связи, согласованность учебных программ, детерминированная дидактическими целями и содержанием. При компетентностном подходе междисциплинарные связи позволяют переносить знания, умения и навыки из одной сферы науки и профессиональной деятельности в другие. Междисциплинарный подход направлен на связь дисциплин, когда сглаживаются противоречия в усвоении знаний, идей, методов и приемов исследования между науками, и происходит комплексное применение в профессиональной деятельности теории и практики, полученных на основе изучения дисциплин. Отмечены, как существенные преимущества, так и проблемы, возникающие при использовании междисциплинарного подхода. Доказано, что умения и навыки будущих бакалавров и магистров специальности «международный бизнес» формируются под воздействием изучения и взаимосвязи с другими дисциплинами. Обоснована необходимость усиления роли гуманитарной и методологической составляющих в преподавании дисциплин специальности «международный бизнес», а также активизации применения различных методов для улучшения восприятия и усвоения различных аспектов функционирования и развития мировой экономики как целостной системы.

Ключевые слова: междисциплинарный подход, междисциплинарные связи, компетенция, интегративный подход, понятийно-терминологический аппарат, профессиональная подготовка по специальности «международный бизнес».

The article deals with the problems of implementation and use of interdisciplinary approach in professional training of future bachelors and masters of the "international business" specialty. Interdisciplinary communication, providing an interdisciplinary approach to education, the scientific base and system of education as a complex of fundamental and taxonomic disciplines are considered. It has been carried out the description and characteristics of the specificity of international business, world economy and international economic relations specialists' professional activity. Applying of interdisciplinary approach in professional training of future bachelors and masters is considered as a part of the formation process of their professional competence due to the realization of the intercourse between the disciplines of humanitarian, social-economic and science training. It contains the consistency of educational programs, determined by didactic goals and content. Interdisciplinary connections with the competence approach allow transferring knowledge, skills and abilities from one sphere of science and professional activity to another. The contradictions in the assimilation of knowledge, ideas and researching methods between the Sciences are smoothed out, and there is a complex application of the theory and practice obtained on the basis of the study of disciplines in professional activities. Both significant advantages and problems arising from the use of an interdisciplinary approach are noted. It has been proved that abilities and skills of bachelors and masters of the "international business" specialty are formed due to the impact of studying and intercourse of different disciplines. The necessity of strengthening the role of the humanitarian and methodological component in teaching international business disciplines is grounded, as well as the activation of the different methods to improve the perception and assimilation of various aspects of the functioning and development of the world economy as an integrated system.

Keywords: interdisciplinary approach, interdisciplinary communication, competence, an integrative approach, conceptual and terminological apparatus, professional training of "international business" specialty.

Постановка проблеми. 3 початку XXI ст. у науці поширилась тенденція синтезу знань у межах суміжних дисциплін, в основі якої лежить парадигма цілісності та міждисциплінарного підходу до досліджень, організації науки і отримання освіти з використанням інноваційних проблемно-проектних методів. Міждисциплінарність перетворилася у термін, 3 одного боку, який містить «інтегративний характер сучасного етапу наукового пізнання», що свідчить про недостатність дисциплінарного, тобто однобічного, «галузевого» принципу пізнання. 3 іншого боку - припускає профресійну мобільність освітнього процесу (оперативне реагування на постійно виникаючі зміни у профресійній, науковій, теоретичній і практичній діяльності), а також симбіоз змістовних аспектів навчання, умінь, навичок і компетенцій.

Мета статті полягає у аналізі можливостей та фрорм впровадження міждисциплінарного підходу при викладанні предметів спеціальності «міжнародний бізнес» у рамках професійної підготовки бакалаврів і магістрів.

Аналіз останніх досліджень і публікацій. Проблематику міждисциплінарності економічної науки в найширшому їі розумінні досліджували Задорожний Г., Гомонюк О., Радіонова Л., Чаплигіна Г., Чекмарьов В. Окрему увагу міждисциплінарному підходу в економічній науці приділили Арутюнов В., Зайцев Ю., Колот А., Липов В., Лисенко Ю., Судаков В., Філіпенко А., Яковенко Л. Однак, у роботах зазначених авторів міждисциплінарність висвітлюється в основному через з'ясування еволюції методу економічної науки, а також через дослідження окремих випадків міждисциплінарності в економіці, залишаючи поза увагою системне дослідження його застосування для економічних спеціальностей міжнародного спрямування. Проведений у рам- 
ках дослідження аналіз наукової літератури показав фррагментарність підходу до якості профресійної підготовки економістів-міжнародників, майбутніх бакалаврів та магістрів на основі міждисциплінарності.

Виклад основного матеріалу дослідження. Сьогодні більшість методів викладання у вузах (особливо економічних дисциплін), як і раніше, фрокусується на вивченні матеріалу і передачі знань без відповідної уваги до нових викликів, що фрормують сучасні екосистеми. Тому сьогодні мова йде про перезапуск існуючої освітньої моделі з фокусом на компетенції і виклики майбутнього.

Тому створення сорокусованої освітньої моделі максимальної цінності можливо за рахунок забезпечення професійного і особистого розвитку студента і $€$ першочерговим завданням, що відповідає новим соціальним запитам щодо підготовки кадрів економічних спеціальностей взагалі і економістів-міжнародників зокрема.

Оскільки міждисциплінарність в освіті поняття ієрархічне, то й іï характер відрізняється як за рівнем складності структурних характеристик вищої освіти, освітніх сорер, напрямів підготовки або спеціальностей, так і за ступеню взаємодії усередині окремих освітніх конструкцій (Oxford Handbook, 2017).

У сучасних умовах багато досліджень у сорері міждисциплінарності (Krasnov, 2018; Осмоловская, Краснова, 2018; Мальцева, Швец, Веселова, 2018) свідчать, що кожна освітня дисципліна має свій об'єкт вивчення та інструментарій, при цьому у багатьох вони збігаються і взаємозалежні, а отже, міждисциплінарний підхід враховує нагромадження інфрормаційної та історичної бази знань. Всебічно охопити її неможливо, тому визначення ключових елементів дисциплін, що збігаються, дозволяє студентам засвоїти і застосовувати базу знань, мінімізувавши ії багатозначне трактування. Отже, у міждисциплінарність припускає два загальноприйнятні підходи:

- перший обумовлює взаємозв'язок двох і більше дисциплін із суміжною термінологією, системою дослідження, об'єктами цих досліджень і т.д., причому ця сукупність допомагає досконало вивчити проблему дослідження, створює широке поле для наукових проектів. При цьому система знань для підготовки майбутніх фрахівців здобуває сучасний вигляд і сприяє вирішенню наукових проблем;

- другий дозволяє розширити галузь знань, які не можуть повноцінно досліджуватися вже існуючими науковими дисциплінами, оскільки перебувають на межі їх перетину. Він сприяє поглибленню знань за умови, коли предмет дослідження занадто складний, а сформульована наукова проблема масштабна для однієї конкретної дисципліни.

Вивчення досвіду провідних світових навчальних закладів в сфері підготовки економістів-міжнародників свідчить про поступову, але сталу реорганізацію, відповідно до вимог ринку, їх освітнього процесу за принципами міждисциплінарності. Це забезпечує виховання універсального працівника з широким спектром базових знань та навичок, здатного виконувати велику кількість різнопланових завдань виробничого та управлінського характеру.

Додатковою перевагою освітніх програм окремих вітчизняних ЗВО $\epsilon$ фрормування загальних компетентностей, що забезпечують здатність комунікувати з представниками інших вітчизняних і зарубіжних професійних груп різного рівня, з експертами з інших галузей знань/видів економічної діяльності, представниками різних видів міжнародного бізнесу, що досягається завдяки мовній фраховій підготовці фрахівців. IMB має передовий досвід в даній ссрері. Зокрема, освітня програма «міжнародний бізнес» першого рівня вищої освіти передбачає обов'язкове вивчення мінімум двох іноземних мов, а також включення до обов'язкового освітнього компоненту дисциплін 3 дипломатичного протоколу, етикету, крос культурного менеджменту, що забезпечує здатність ефективної комунікації в сучасних умовах багатокультурного бізнес-середовища.

Окрім того, міждисциплінарний підхід, що реалізується в рамках освітніх програм «міжнародного бізнесу», повністю корелюється 3 загально задекларованими принципами вищої освіти, закріпленими рядом відповідних актів, зокрема Законом України «Про вищу освіту» та стандартами вищої освіти за спеціальністю 292 «Міжнародні економічні відносини» для першого та другого рівнів вищої освіти.

Тому, впровадження міждисциплінарного підходу на кафедрі міжнародного бізнесу Інституту міжнародних відносин Київського національного університету ім. Тараса Шевченка за спеціальністю «міжнародні економічні відносини» освітніх програм «міжнародний бізнес» першого та другого рівнів вищої освіти, реалізується сьогодні у наступних фрорматах: а) включення головного напряму міждисциплінарних тем у курс лекцій з міжнародного бізнесу і міжнародному менеджменту, що надає можливість досить широко здій- 
снити аналіз проблем і методів дослідження на перетині наук і навчальних дисциплін; б) впровадження у семінарські та практичні заняття дисциплін загальних кейсів 3 міжнародного бізнесу, міжнародних менеджменту та маркетингу для рішення міждисциплінарних практичних завдань та інших сучасних освітніх технологій проблемного навчання; в) розробка і впровадженні послідовних міждисциплінарних курсів для дисциплін на вибір за спеціалізованими блоками «Міжнародний бізнес та ділове адміністрування», «Міжнародний менеджмент і маркетинг», «Фінанси міжнародного бізнесу» та ін.) з метою їх поглибленого вивчення.

Кафедра у своїй викладацькій діяльності виходить із того, що міждисциплінарний підхід, 3 одного боку, спрямований на зв'язок дисциплін (згладжуються протиріччя у засвоєнні знань, ідей, методів між науками), 3 іншого - сприяє комплексному застосуванню теорії і практики, отриманих на основі вивчення дисциплін, у профресійній діяльності. Крім того, міждисциплінарні зв'язки за часом впровадження визначаються як: попередні; паралельні; повторювані; перспективні; а за можливостями перенесення знань як: теоретичні, логічні, фрілософрські, семіотичні, практичні. Усі вони не лише розширюють, але й створюють новий освітній простір (у т.ч. наукову базу на перетині суміжних дисциплін), у якому майбутні економісти-міжнародники можуть освоїти знання, уміння і навички у межах компетентного підходу (інтеграція проблемно-орієнтованого викладання з новими дисциплінами поглиблює і збагачує вже існуючі). Основною метою реалізації міждисциплінарного підходу в навчальному процесі $€$ досягнення єдиної базової інтегральної компетенції, що являє собою здатність виявляти, аналізувати, оцінювати і вирішувати актуальні, складні, комплексні проблеми і завдання у сорері міжнародного бізнесу, приймати самостійні, обґрунтовані, виважені рішення та генерувати нові, креативні ідеї щодо управління міжнародними бізнес процесами під час навчання, що передбачає проведення теоретичних і практичних досліджень, здійснення інновацій і характеризується ризиками і невизначеністю умов та вимог. Такий підхід забезпечує та гарантує отримання здобувачами вищої освіти найбільш актуальних знань, навичок, освітніх та професійних кваліфрікацій, оптимально адаптованих до сучасного стану вітчизняної та світової економіки в усіх іiї розрізах та вимірах: як зі сторони держави та регулятора, так і зі сторони приватного сектору, некомерційних організацій, експертноаналітичного та академічного секторів.

Однак, як з'ясувалося, впровадження міждисциплінарного підходу має низку особливостей, що виникають при викладанні предметів для майбутніх економістів-міжнародників спеціальності «міжнародний бізнес». Так, кафредрою міжнародного бізнесу визначена етапність його впровадження на основі чітких принципів роботи міждисциплінарного колективу педагогів (попередньо були визначені сорери відповідальності за загальну термінологію, прийнятність трактування методології, обмірковані методики синтезу знань).

Перший, найважливіший етап - розробка суміжної базової термінології. Цей етап викладацьким колективом кафедри був успішно пройдений - міждисциплінарний підхід був використаний для усунення спірних (споріднених) трактувань базових термінів, а власне понятійний апарат за цих умов слугував фрундаментом для початку викладання і умовою засвоєння матеріалу 3 економічних дисциплін (особливо суміжним). Уніфрікація понятійно-категоріального апарату, а також узагальнення концептуальних підходів в рамках базових дисциплін, розроблених та структурованих науково-педагогічним колективом кафредри, представлено в ряді опублікованих навчальних підручників, посібників, монографрій, статей, основним серед яких $€$ підручник «Міжнародний бізнес», який використовується в процесі підготовки фрахівців економічного профрілю. При цьому, структурування освітньої програми «міжнародний бізнес» відбувалося за наступними принципами: 1) зміст навчального матеріалу відповідає встановленому рівню теоретичної і практичної підготовки з основних економічних дисциплін; 2) нагромадження теоретичної і практичної бази за міждисциплінарним курсом включає дисципліни на вибір і програми практик; 3) зміст дисциплін розкриває методи наукового дослідження на основі міждисциплінарних зв'язків; 4) комплекс засобів з оцінювання для проміжної атестації, спрямований на перевірку рівня сорормованих загальних і просресійних компетенцій, сфрормований із урахуванням міждисциплінарних зв'язків; 5) викладачі можуть постійно підсилювати паралельні, перспективні та інші міждисциплінарні зв'язки дисциплін, що повторюються, (професійноорієнтовані та учбово-пізнавальні завдання, які спрямовані на фрормування компетенції або її частини). При впровадженні принципу міждисциплінарності кафедрою міжнародного 
бізнесу IMB були проведені наступні заходи: a) визначені педагогічні і загальнодидактичні умови, що сприяють викладанню на основі міждисциплінарних зв'язків; б) погоджено за часом освоєння суміжного комплексу знань, навичок і вмінь економічних дисциплін; в) розроблена загальна понятійна, теоретична і практична база, у якій збігаються десрініції, наукові методи навчання студентів.

На другому етапі перед викладацьким складом кафедри, при впровадженні міждисциплінарного підходу у викладацькі дисципліни, постала така проблема як багатозначність застосування загальної термінології (полісемія), яка ускладнює сприйняття матеріалу студентом. Крім того, виникла також проблема розбіжності спеціалізованих мов і понятійного апарата різних економічних дисциплін (включаючи експертизи міждисциплінарних досліджень, що здійснюються студентами у межах бакалаврських і магістерських робіт). Це зажадало не лише розширення понятійного апарату курсів і спецкурсів, але й структурування його по-новому (іноді цей процес торкався навіть елементів базової термінології). Однак і цей етап кафедрою міжнародного бізнесу також був успішно пройдений. На цьому етапі була сорормована система компетентностей на основі безперервності і спадкоємності міждисциплінарного комплексу, а дисципліни класисрікувалися за наступними видами міждисциплінарних зв'язків: попередні (дисципліни, при вивченні яких, засвоєні десрініції і методи дослідження, які є базовими та будуть застосовуватися у подальшому вивченні інших дисциплін); паралельні і повторювані (дисципліни, що вивчають загальні та суміжні напрями професійної діяльності, де використовується загальний термінологічний і методологічний апарат); перспективні (дисципліни, для яких набуті знання і навички стануть опорними, тобто будуть використовуватися у професійній діяльності).

Сьогодні, на третьому етапі, касредра бачить реалізацію наступних завдань. По-перше, розробка критеріїв експертизи міждисциплінарних досліджень, що дозволяють оцінити результати педагогічної і науково-дослідної роботи касредри. По-друге, розробка і впровадження викладачами міждисциплінарних кейсів у комплекс засобів 3 оцінювання придбаних студентами знань. По-третє, розробка «портореля» навичок і універсальних компетенцій (когнітивних, соціальних і поведінково-особистих), що сприяє фрормуванню у студентів наступних умінь: а) вирішувати проблемні завдання; б) здійснювати аналіз і встановлювати причиннонаслідкові зв'язки між фрактами та подіями; в) виділяти істотні властивості і ознаки об'єктів та явищ; г) самостійно ухвалювати нестандартні рішення в умовах невизначеності; д) використовувати критичне мислення для розвитку творчих здібностей, а також самостійність та відповідальність.

Хоча за своїм характером універсальні компетентності є загальними для багатьох навчальних дисциплін, вони забезпечують цілісність особистого та пізнавального розвитку і саморозвитку, міждисциплінарність і спадкоємність організації профресійної підготовки майбутніх економістів-міжнародників.

При цьому, по-перше, дослідницькі і проектні роботи повинні носити інтегративний, міждисциплінарний характер і відповідати пізнавальним інтересам та професійним запитам студентів. По-друге, використання методів ситуаційного навчання сприяє придбанню практичного досвіду у реальних існуючих у повсякденному житті і профресійної діяльності ситуацій (у т. ч., розвиток «дослідницької позиції», відповідальність за наслідки ухваленого рішення і т. п.).

Критично необхідним, в даному випадку, $€$ реалізація практичної орієнтації освітніх програм за рахунок активного впровадження в навчальні плани корпоративних модулів, майстер-класів та практикумів. У зв'язку 3 цим, творчо переосмисливши традиційні процедури/срорми навчальної роботи, колектив кафедри міжнародного бізнесу наразі розробляє універсальний алгоритм поєднання методів оцінки профресійних знань, умінь і навичок, що склалися, з інноваційними моделями оцінки соціально-особистих і системних компетенцій з позицій міждисциплінарної інтеграції.

Дійсно, міждисциплінарна інтеграція визначає багаторівневий підхід, заснований на концепції, що навчальна і профресійна діяльність $€$ адекватною підставою для інтегративного синтезу знань, надійним і ефективним засобом забезпечення спадкоємності у фрормуванні універсальних компетенцій (Лысак, 2016; Крепс, 2019; Gomonyuk, 2019). Методичні розробки касредри міжнародного бізнесу сьогодні ґрунтуються на наступному двофакторному принципі. 3 одного боку, саме когнітивні навички (узагальнення, порівняння, абстрагування, конкретизація та ін.), інтегративні фрорми навчання, активні та інтерактивні методи і технології навчання (ділові ігри, імі- 
таційні ігри і вправи, кейс-метод, технологія проектного навчання, дискусії та «мозковий штурм») поступово переростають у відповідні профресійно визначальні компетенції. 3 іншого боку - не менш важливі і внутрішньодисциплінарні зв'язки, реалізація яких може здійснюватися на рівні виконання проблемних завдань, вирішення проблемних ситуацій, проектної діяльності студента. Це сприяє розвитку його як особистості, що вільно й свідомо орієнтується у просторі соціуму, здатної до самоактуалізації і самореалізації в умовах різноманітних соціальних відносин і взаємодій.

Сьогодні кафедра міжнародного бізнесу IMB $€$ ініціатором створення міжкафредральної моделі «Проектне мислення і освітні IКТ». Існує пряма залежність між ефрективністю виконання навчальних програм і ступенем інтеграції в них відповідних IКТ. В останні роки виникли протиріччя між мотиваційними стимулюючими аспектами навчання студентів, пасивно-споглядальними i активно-перетворювальними видами навчальної діяльності, психологічним комсоортом і дискомсооттом, стандартом навчання і індивідуальним розвитком, суб'єктосуб'єктними і суб'єкто-об'єктними відносинами. Розуміння того, що проблема оцінки ефективності впровадження IКТ $€$ досить складною, багатоплановою і не має остаточного рішення, кафредра міжнародного бізнесу зосередила увагу на двох принципах створення інтерактивного інсрормаційно-освітнього середовища (IOC) для відділення «міжнародний бізнес». Це інтегральність (сукупність базових знань і міждисциплінарних зв'язків) і багатокомпонентна адаптивність (гнучкі системи контролю знань, бази даних та інформаційно-довідкові системи). Згідно вищезазначеного реалізація моделі ґрунтується на наступних передумовах.

По-перше, сьогодні потенціал IOC IMB (технічне оснащення та рівень кваліфрікації фрахівців з обслуговування комп'ютерної техніки) досить високий. Однак, усе більш актуальної постає проблема реалізації освітніх інсрормаційних технологій у інваріантних середовищах і стандартах при читанні курсів зі спеціальності міжнародний бізнес і міжнародні економічні відносини в цілому. Тому, основними напрямами впровадження IKT $€$ їх використання у якості: a) засобу навчання, що вдосконалює процес викладання і управління навчальним процесом; б) інструмента творчого розвитку студента (пізнання власної індивідуальності та дійсності); в) засобу автоматизації процесів контролю, корекції, тестування і психодіагностики, передачі і придбання педагогічного досвіду.
По-друге, важливими є не власне IKT, а їх взаємодія з навчанням і роль у контексті освітньої системи у цілому, що надає можливість, з одного боку, доступу студентів і викладачів до структурованих учбово-методичних матеріалів, що навчають мультимедійним комплексам усього університету у будь-який час і в будь-якій місці перебування студента. 3 іншого - забезпечення студента зв'язком із викладачем, одержання консультацій у он-лайн або офрф-лайн режимах, індивідуальної «навігації» у освоєнні дисциплін. Це підвищує фрундаменталізацію освітнього процесу на всіх його рівнях, прискорює реалізацію концепцій випереджальної освіти на основі використання інноваційних методів.

По-третє, кафредрою міжнародного бізнесу активно розглядається питання про впровадження мережевої форми навчання з окремих дисциплін спеціалізації «міжнародний бізнес», що створює можливість освоєння студентом освітньої програми з використанням ресурсів декількох освітніх організацій (університетів) України, у тому числі іноземних, з якими IMO укладені угоди про співробітництво.

Тому стратегічними пріоритетами на найближчі два роки для кафедри міжнародного бізнесу є: 1) перегляд змісту і методів викладання 100\% програм у режимі «на випередження» - фрокус на компетенції, що будуть актуальні впродовж наступних 3-5 років, розробка портореля освітніх програм, що мають бути пристосовані до викликів майбутнього; 2) формування індивідуальних освітніх траєкторій спеціальності «міжнародний бізнес» на основі змішаного навчання (комбінація традиційного контактної освіти і електронного навчання з використанням цифррових технологій) та переходу до адаптивних освітніх траєкторій у цифрровому просторі; 3) створення комплексу спеціалізованих магістерських програм із прив'язкою до запитів роботодавців, галузевих експертів, механізмів працевлаштування і з урахуванням перспективних ніш на ринку праці з обрієм не менше ніж 3-5 років; 4) впровадження системи 5-6 кар'єрних треків, заснованих на інноваційному підприємництві і стартап-проектах міждисциплінарного характеру, з якими можуть ознайомитися потенційні роботодавці через цифровий хмарний простір; 5) конвертування програм другої освіти IMO у сучасні мережні форми з використанням цисррових технологій і розпакування цих програм у окремі модулі; 6) використання у контексті IT-інсрраструктури IMO принципу модульності для дисциплін, що викладаються за спеціальністю «міжнародний бізнес», і диверси- 
срікація процесів їх технічного обслуговування (створення віртуальних комп'ютерних класів і віртуальних робочих місць, відеоконсеренцій і відеолекторіїв); 7) для талановитих студентів, які не спроможні сплачувати навчання, розпочати загальноінститутську програму з розвитку кредитних освітніх продуктів з банками-партнерами, розширюючи «вікно можливостей» для талантів.

Висновки. Сьогодні міждисциплінарність освіти не лише вносить відповідну змістов- ність інваріантної частини освітнього процесу, але й сприяє розбудові у студентів швидкої і адекватної реакції на нові технології, нові виклики світових ринків у нерівновагих умовах невизначеності, зберігаючи баланс мінливості та стабільності. Однак, важливою проблемою епістемології залишається розробка як критеріїв експертизи міждисциплінарних підходів в освіті, що дозволяють оцінити новаторські роботи, так і методів запобігання дилетантизму і непрофресіоналізму в освіті.

\section{СПИСОК ВИКОРИСТАНИХ ДЖЕРЕЛ:}

1. Fossen F.M., Zongner A. (2019) New Digital Technologies and Heterogeneous Employment and Wage Dynamics in the United States: Evidence from Individual-level Data. IZA Discussion Paper 12242. Bonn : Institute of Labor Economics.

2. OECD (2018) Education 2030: The Future of Education and Skills. Paris: OECD, 2018. URL: https://www.oecd.org/education/2030-project/teaching-and-learning/learning/skills/Skills_for_2030.pdf

3. Brynjolfsson E., Mitchell T., Rock D. (2018) What Can Machines Learn and What Does It Mean for Occupations and the Economy? // American Economic Association Papers and Proceedings, (108): 43-47.

4. Immerman D. (2019). Digital Twin Predictions: The Future Is Upon Us. Industrial Internet of Things, PTC. URL: https://www.ptc.com/en/product-lifecycle-report/digital-twin-predictions

5. The Oxford Handbook of Interdisciplinarity (2017) Second Edition / Editor-in-chief R. Frodeman. Associate editors J. T. Klein and R. C. S. Pacheco. Oxford University Press.

6. Родіонова Л. (2014) Напрями розвитку економічної теорії на початку XXI ст. [Trends of economic theory development in the early twenty-first century]. // Збірник Тернопільського університету, (2): 159-170. URL: http://dspace.tneu.edu.ua/handle/316497/4673

7. Vakhshtayn V. S., Erofeeva M. А. (2015) Эпистемические Интервенции: В Поиске Новых Моделей КроссДисциплинарного Взаимодействия [Epistemic interventions: in the search for new models of cross-disciplinary interaction]. URL: http://ssrn.com/abstract=2531289

8. Future Agendas for Global Education 2017. URL: https://asi.ru/upload/iblock/2e8/GEF.Agenda_eng.pdf

9. Krasnov S.V. etc (2018) Problems of Quality of Education in the Implementation of Online Courses in the Educational Process // International Conference on High Technology for Sustainable Development (HiTech), Sofia-2018. URL: https://doi.org/10.1109/HiTech.2018.8566618

10. Осмоловская И.М., Краснова Л.А. (2018) Процесс обучения с позиции междисциплинарных исследований [The learning process from the perspective of interdisciplinary research] // Образование и наука. 20(8): 9-27. URL: https://doi.org/10.17853/1994-5639-2018-8-9-27

11. Мальцева А.А., Швец И.М., Веселова Т.А. (2018) Междисциплинарность как средство достижения результатов, способствующих становленню образования для устойчивого развития [Interdisciplinarity as a means of achieving results contributing to the formation of education for sustainable development] // Современное образование, (4): 32-44. URL: https://nbpublish.com/library_read_article.php?id=27622

12. Лысак И.В. (2016) Междисциплинарность: преимущества и проблемы применения [Interdisciplinary: advantages and problems of application] // Международный журнал “Современные проблемы науки и образования", (5). URL: http://science-<education.ru/ru/article/view?id=25376

13. Крепс Т.В. (2019) Междисциплинарный подход в исследованиях и преподавании: преимущества и проблемы применения [Interdisciplinary approach in research and teaching: advantages and problems of application] // Научный вестник Южного института менеджмента, (1): 115-120. URL: https://doi.org/ 10.31775/2305-3100-2019-1-115-120

14. Gomonyuk O.M. (2019) Implementation of an interdisciplinary approach to the professional training of future bachelors in finance, banking and insurance // Modern information technologies and innovative teaching methods in the training of specialists: methodology, theory, experience, problems. Kyiv-Vinnitsya : "Glider", (53): 90-94.

15. Deloitte Global Human Capital Trends (2019). Leading the social enterprise: Reinvent with a human focus. URL: https://www2.deloitte.com/content/dam/Deloitte/cz/Documents/human-capital/cz-hc-trends-reinvent-with-humanfocus.pdf 


\section{REFERENCES:}

1. Fossen F.M., Zongner A. (2019) New Digital Technologies and Heterogeneous Employment and Wage Dynamics in the United States: Evidence from Individual-level Data. IZA Discussion Paper 12242. Bonn: Institute of Labor Economics.

2. OECD (2018) Education 2030: The Future of Education and Skills. Paris: OECD, 2018. Available at: https://www.oecd.org/education/2030-project/teaching-and-learning/learning/skills/Skills_for_2030.pdf

3. Brynjolfsson E., Mitchell T., Rock D. (2018) What Can Machines Learn and What Does It Mean for Occupations and the Economy? // American Economic Association Papers and Proceedings, (108): 43-47.

4. Immerman D. (2019) Digital Twin Predictions: The Future Is Upon Us. Industrial Internet of Things, PTC. Available at: https://www.ptc.com/en/product-lifecycle-report/digital-twin-predictions

5. The Oxford Handbook of Interdisciplinarity (2017) Second Edition / Editor-in-chief R. Frodeman. Associate editors J. T. Klein and R. C. S. Pacheco. Oxford University Press.

Rodionova L. (2014) Directions for the development of economic theory at the beginning of the 21st century /I Bulletin of Ternopil NEU, (2): 159-170. Available at: http://dspace.tneu.edu.ua/bit-stream/316497/4673/1/ Родіонова\%20Л.pdf (in Ukrainian)

6. Vakhshtayn V. S., Erofeeva M. A. (2015) Epistemic interventions: in the search for new models of cross-disciplinary interaction. Available at: http://ssrn.com/abstract=2531289 (in Russian)

7. Future Agendas for Global Education 2017. Available at: https://asi.ru/upload/iblock/2e8/GEF.Agenda_eng.pdf

8. Krasnov S.V. etc (2018) Problems of Quality of Education in the Implementation of Online Courses in the Educational Process // International Conference on High Technology for Sustainable Development (HiTech), Sofia-2018. Available at: https://doi.org/10.1109/HiTech.2018.8566618

9. Osmolovskaya I.M., Krasnova L.A. (2018) The learning process from the perspective of interdisciplinary research // Education and Science. 20(8): 9-27. Available at: https://doi.org/10.17853/1994-5639-2018-8-9-27 (in Russian)

10. Maltseva A.A., Shvets I.M., Veselova T.A. (2018) Interdisciplinarity as a means of achieving results contributing to the formation of education for sustainable development // Modern Education, (4): 32-44. Available at: https://nbpublish.com/library_read_article.php?id=27622 (in Russian)

11. Lysak I.V. (2016) Interdisciplinary: advantages and problems of application // Internet journal "Modern problems of science and education", (5). Available at: http://science-education.ru/ru/article/view?id=25376 (in Russian)

12. Kreps T.V. (2019) Interdisciplinary approach in research and teaching: advantages and problems of application // Scientific bulletin of the Southern Institute of Management, (1): 115-120. Available at: https://doi.org/ 10.31775/2305-3100-2019-1-115-120 (in Russian)

13. Gomonyuk O.M. (2019) Implementation of an interdisciplinary approach to the professional training of future bachelors in finance, banking and insurance // Modern information technologies and innovative teaching methods in the training of specialists: methodology, theory, experience, problems. Kyiv-Vinnitsya: "Glider", (53): 90-94.

14. Deloitte Global Human Capital Trends (2019) Leading the social enterprise: Reinvent with a human focus. Available at: https://www2.deloitte.com/content/dam/Deloitte/cz/Documents/human-capital/cz-hc-trends-reinventwith-human-focus.pdf 